\title{
The 2009 Educational Reforms in Nigeria: An Evaluation of the Policy on Access and Gender Parity
}

\author{
Lawal Bala Isa \\ Department of Public Administration, Ahmadu Bello University, Zaria-Nigeria
}

\begin{abstract}
In spite of the pivotal role of education to the advancement of mankind, the opportunities for enrolment in tertiary education in Nigeria were grossly inadequate for the needs of the country. Access to higher education, gender parity and the lack of capacity of the system to absorb the numbers of candidates seeking admission to higher educational institutions among others, continue to pose serious problems to the attainments of education sector goals in the country. This paper is aimed at evaluating the 2009 educational reforms benchmarks towards the development of tertiary institutions in Nigeria. The paper relied on secondary source of data. Official publication of Federal Ministry of Education, United Nations Educational, Scientific and Cultural Organization (UNESCO) country reports, Roadmap for Education (2009) and JAMB Annual Reports/publications were used for descriptive and analytical purposes. The paper established that for the period under review 2011-2016, the $20 \%$ annual increase in admission benchmark though reasonably achieved with $62 \%$ positive variance, the gap between those admitted and candidates left out continue to grow, thus out of the 7.5 million candidates that applied for placements into Nigerian tertiary institutions, only about 1.7 million candidates were admitted $(21.9 \%)$ leaving out $78 \%$ or 5.9 million from opportunities for tertiary education and the reform benchmark on gender equity $(55 \% / 45 \%$ malefemale) was yet to be achieved. The paper recommends for the expansion of the activities of National Open University of Nigeria (NOUN), Open and Distance Learning (ODL) and National Teachers' Institute (NTI) with improved facilities, advancement of Technical and Vocational Education (TVE) programmes, and increase of carrying capacity of tertiary institutions without compromising standards. Also that female admission ratio into tertiary institutions should be improved with continuous gender focused education programmes.
\end{abstract}

Keywords: Education, Access to education, Gender parity, Quality education

DOI: $10.7176 / \mathrm{PPAR} / 10-11-02$

Publication date: November $30^{\text {th }} 2020$

\section{INTRODUCTION}

Throughout the world, education has been valued as a means of addressing socio-economic inequalities where they exist and for transforming societies and cultures. The general acceptability of education as the most desired instrument for political, economic, social and technological development and advancement globally is not debatable.

In spite of the pivotal role of education to the advancement of mankind, the opportunities for enrollment in tertiary education in Nigeria were grossly inadequate for the needs of the country. Access to higher education and the lack of capacity of the system to absorb the numbers of candidates seeking admission to higher educational institutions continue to pose serious problems. For example, it was estimated that as at 2009 out of 400,000 JAMB candidates seeking admission to university education, more than 320,000 , which is about $80 \%$ were not able to gain admission to any of the 37 Nigerian Universities. In 2013, 1.7million candidates registered for Nigeria's centralized tertiary admission examinations conducted by Joint Admission and Matriculation Board (JAMB), all competing for the half million places available, potentially leaving over a million qualified college age Nigerians without a post-secondary place(FME Report, 2009).

This gap in access to tertiary education in Nigeria was remarked upon by Clark (2005), and the former Minister of Education, Prof. Ruqaiyyatu Rufai (FME Report, 2014), that only about one-third of applicants get placed in the tertiary institutions through JAMB annually. More disturbing is the scenario where $40 \%$ of applicants averagely over the years (2008-2015) pass the UTME but only $18.8 \%$ get admitted in the tertiary institutions in Nigeria leaving $21.2 \%$ who have passed but not placed. This situation is frustrating both to the qualified candidates and their parents and as such, the frustrated candidates may engage in untoward activities and even constitute security threat to the society.

Another militating factor to achieving the mission and vision of any university system is the lecturer/requisite staffing. According to United Nations Educational, Scientific and Cultural Organization(UNESCO, 2007) cited in Okebukola (2008); there is a plethora of evidence suggesting that teacher quantity, quality and motivation exert noteworthy effects on a host of school variables especially enrolment, participation and achievements of pupils. According to Federal Ministry of Education (2009), the total number of academic staff in the Nigerian University System (NUS) as at 2006 is 27,394 but, about 50,000 (meaning a shortfall of 22,606 academic staff) is required for effective course delivery across the disciplines. For the Polytechnic, the required number of academic staff is 22,702 while the actual was 12,938. For the Colleges of Education, the actual was 11,256 while the number 
required is 26,114 . The implication of this obvious shortfall in the number of academic staff may include; high academic staff/students ratio and severe stress on the academic staff on ground. This shortfall in the number of academic staff can further lead to low productivity and decline in the quality of teaching in the Nigerian University System (Okebukola, 2008; FME, 2009).

Inadequate and obsolete infrastructure and equipment as well as poor library facilities remain one of the major challenges in the Nigerian tertiary institutions. Thus, about $15-30 \%$ of the infrastructure, equipment and books are non-functional, obsolete or dilapidated (FME Report, 2009). Furthermore, the classrooms, laboratories and the general environment of most universities in Nigeria are still far from a state that will promote optimal learning, teaching and research (Okebukola, 2008).

However, there is empirical evidence that the quality of graduates produced in Nigeria in the last decade was of low quality and thumbed down the quality of those that would graduate in the present decade (Okebukola, 2006). As reported by Federal Ministry of Education (2015), the quality of graduates dropped from $72 \%$ in 1979 to $68 \%$ by 1999 . Only $10 \%$ of the 130,000 students that graduate from Nigerian universities annually are able to secure paid employment. In fact, the non-inclusion of any of the Nigerian's Universities in the world best 500 Universities and worst still, Nigeria ranked (then) 44 after Ghana, Kenya, South Africa in ranking of African Universities is a factor to be reckoned with.

In view of the above, the problem worthy of investigation in this paper is to what extent has the implementation of the 2009 Educational Reform improved access to education and by extension, reduced gender parity in federal tertiary institutions in Nigeria? In specific terms, what are the performance indices on the two (2) prescribed benchmarks as contained in 2009 Education Reform?

i. $20 \%$ increase in admissions annually from 2011 in the tertiary institutions, and

ii. Attainment of at least $55 \% / 45 \%$ gender parity/equity in admissions by 2011 . Thus by $2016-201850 \%$ parity ratio or equality.

\section{REVIEW OF RELATED LITERATURE}

Education is a worthwhile venture as it is recognized worldwide as the most important engine that propels technology and national development in modern societies (Shagari, Bello and Umar, 2013). It can be said that educational reforms emanate from the basic conviction that considerable progress can be made in a nation by its people through careful engineering of the educational process. The current reform agenda (FME Roadmap, 2009) and transformation programmes of the Federal Government of Nigeria are part of the historical attempts to direct public attention to necessary changes that must be undertaken collectively and separately to address our daunting challenges in public and private spheres, especially in higher education.

The conceptualization of access to education reflects the universal declaration of human rights, which asserts that everyone has a right to education that should provide a guarantee for everyone entitled to education to receive it; it implies the educational opportunities or means of making available within the reach of every citizen of a nation (Enaohwo, 2008). Access to education in its full and broad sense, means free and unlimited, unhindered and unfettered opportunities at each level of education to obtain knowledge, skills, and abilities available at that level needed to optimally participate and contribute to development in the society (Okeke, 2008). However, the 1999 Constitution of the Federal Republic of Nigeria (as amended) provides for free education to the citizenry when practicable (FRN, Section 18 Subsection 1, 3a-d).

Further, access to education covers the threshold of access/enrolling, attending and completing and possibly transiting to the appropriate level of education. Thus, lack of access to education means any of the following: failing to enroll in an education institution; lack of opportunities to attend school regularly; does not complete the prescribed programme of study; does not have to transit to the next level of education. Quality education is measured by the extent to which the training received from an institution enables the recipient to think clearly, independently and analytically to solve relevant societal problems in any given environment. Hence quality in education means relevance and appropriateness of the education programme to the needs of the community and country (Yoloye, 1989). Quality assurance in the tertiary institutions implies the ability of the institutions to meet the expectations of the users of manpower in relation to quality acquired by their outputs (Okebukola, 2005). Further, it can also include the ability of tertiary institutions to meet certain criteria relating to academic matters, staff- students ratio, staff mix by rank, staff development, physical facilities, funding and adequate library facilities (NUC, 2007).

Related to this study, UNESCO (2006) established that women have benefited in the expansion of higher education in Nigeria ( $41 \%$ female) though this is lower than some other sub-Saharan African Countries where women enrolment exceeded that of men (Cape Verde 55\%, Lesotho 55\%, South Africa 55\%, Mauritania 53\%) or at par with men (Swaziland 50\% and Botswana 50\%). The UNESCO report recommended gender equality in higher education. Oyaziwo (2012) worked on "Increasing Access to University Education in Nigeria, Present Challenges". The study recognized the fact that low access to university education in Nigeria could be the result of the problem of carrying capacity; infrastructural/facilities challenge; inadequate public financing; economic 
constraints; labour market failure (low absorptive capacity of economy; and problem of curriculum and curriculum delivery). Towards achieving greater access to university education in Nigeria, the study recommended curbing financial waste in the Nigeria university system (applying the policy of consolidation to its letter); downsizing the number of support staff in Nigerian university system; retraining of Nigerian universities, academic staff to embrace ICT e-learning; and revision of Education Trust Fund support for the production of books and journals in the Nigerian tertiary institutions to include production of online materials for distance learning centers that would serve the greater populace desiring university education.

Anselm (2013) on "Effect of Reforms in Nigerian Educational Sector" found out that, although the workers were aware of the intention of the federal government in initiating the reforms; they noted its poor implementation which caused untold hardship to staff affected by the exercise. The poor implementation of the reform agenda made the attainment of the objectives of the reform unsustainable and unattainable. Recommendations were that, the implementation of reforms in colleges of educations should be executed in such a manner that all the workers and other stakeholders that are affected would be adequately and timely compensated. Workers should be paid all their entitlements and be made to adjust properly to avoid loss of confidence from the work force. However, the study was limited to colleges of education, leaving other tertiary institutions such as universities and polytechnics which this present study attempts to fill the gap. Akpan and Etor (2016) conducted a study on "The Relationship between Accreditation of Academic Programmes and Quality University Education in South -South Nigeria". The study used simple random and accidental sampling techniques to sample 4 Federal Universities, 400 academic staff, 300 final year students and 200 employers for the study. The study revealed that, the level of adequacy of requirements for accreditation of academic programmes was moderately adequate and the quality of university graduates was rated as being moderate. There was a significant relationship between accreditation of academic programmes and quality university education in terms of quality inputs and quality processes. There was also a significant difference between lecturers and students in their perceptions of quality university education. The study recommended among others, that institutional administrators should ensure that the requirements for accreditation of academic programmes be sufficiently provided in universities to enhance quality education.

\section{METHODOLOGY}

This paper relied on secondary source of data. Official publication of Federal Ministry of Education Annual Reports, UNESCO country reports, Roadmap for Education (2009) and JAMB annual reports/publications were used for descriptive and analytical purposes.

RESULTS AND DISCUSSION

Table 1: JAMB Applications and Admission, 2008-2016

\begin{tabular}{|c|c|c|c|c|c|c|c|c|}
\hline $\begin{array}{c}\text { A } \\
\text { Years }\end{array}$ & $\begin{array}{c}\text { B } \\
\text { Applicants }\end{array}$ & $\begin{array}{c}\mathrm{C} \\
\text { Admitted }\end{array}$ & $\begin{array}{c}\text { D } \\
\% \\
\text { Admitted }\end{array}$ & $\begin{array}{c}\text { E } \\
\text { Not } \\
\text { Admitted }\end{array}$ & \begin{tabular}{lr}
\multicolumn{2}{c}{ F } \\
$\%$ & Not \\
Admitted
\end{tabular} & \begin{tabular}{l}
\multicolumn{1}{c}{ G } \\
Actual \\
$20 \%$ of \\
Admitted
\end{tabular} & \begin{tabular}{l}
\multicolumn{1}{c}{ H } \\
Expected \\
$20 \%$ \\
Annual \\
Increase \\
\end{tabular} & $\begin{array}{l}\quad \text { I } \\
\text { Variance } \\
\text { from } \\
2011(\mathrm{H}-\mathrm{C})\end{array}$ \\
\hline 2008 & 1054082 & 118691 & 11 & 935391 & 89 & 23738 & NIL & NIL \\
\hline 2009 & 1306005 & 190786 & 15 & 1115219 & 85 & 38157 & 214524 & 23738 \\
\hline 2010 & 1404111 & 192255 & 14 & 1211856 & 86 & 38451 & 230412 & 38157 \\
\hline 2011 & 1493607 & 98296 & 7.0 & 1395311 & 93 & 19659 & ---------- & ---------- \\
\hline 2012 & 1503933 & 410157 & 27 & 1093776 & 73 & 82031 & 117955.2 & -292201.8 \\
\hline 2013 & 1668314 & 400269 & 24 & 1268045 & 76 & 80054 & 141546.2 & -258722.8 \\
\hline 2014 & 1551289 & 393573 & 25 & 1157716 & 75 & 78715 & 169855.5 & -223717.5 \\
\hline 2015 & 1329876 & 353697 & 27 & 976179 & 73 & 70739 & 203826.6 & -149870.4 \\
\hline 2016 & NA & NA & NA & NA & NA & NA & NIL & NIL \\
\hline Total & 7547019 & 1655992 & & 5891027 & & & 633183.5 & -1022808.5 \\
\hline
\end{tabular}

Source: JAMB Report, 2017 and https://punching.com/Jamb,2019: NA=Not Available

Table 1 shows the total number of JAMB applications and admissions between 2008 and 2016 when the reform benchmarks were expected to be achieved. The table shows that the $20 \%$ annual increase in admission benchmark though reasonably achieved with $62 \%$ positive variance, the gap between those admitted and candidates left out continue to grow, thus out of the 7.5 million candidates that applied for placements into Nigerian tertiary institutions, only about 1.7 million candidates were admitted (21.9\%) as against 633,183.5 thousands expected annual increase. Hence, an average of $40 \%$ (yearly) over the period passed the UTME but only $18.8 \%$ secured admission (2008-2015) leaving 21.2\% who had passed but were not admitted by JAMB. 
Figure 1:Trend in JAMB Admission, 2008-2015

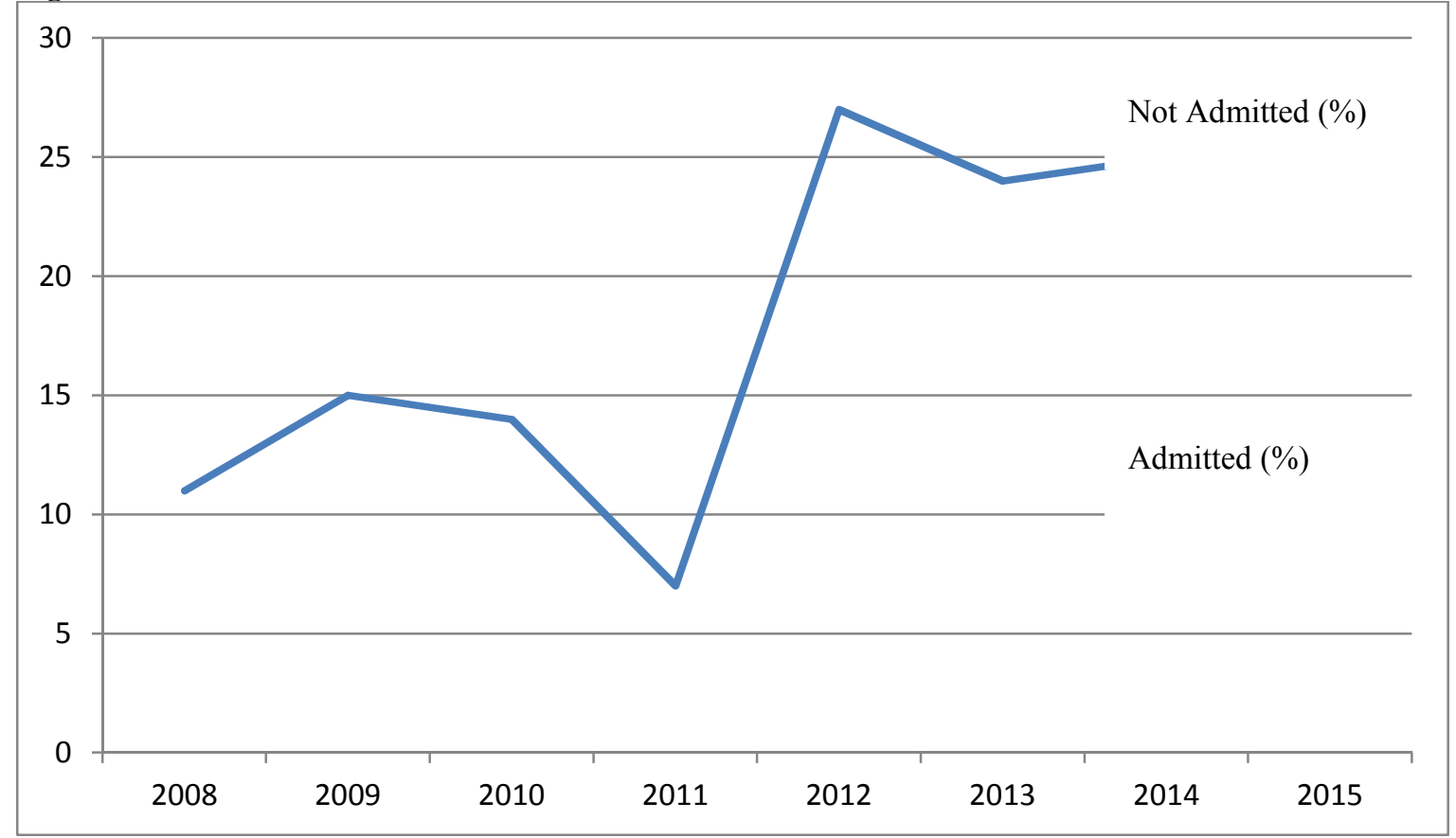

Source: Author's Computation, 2020

Figure 1 shows the trend in those admitted and not admitted in the tertiary institutions in Nigeria for the period under review which indicates that there was a wide gap between those that were admitted against the applicants, particularly, in 2011 where $93 \%$ of the applicants were not admitted while from 2012 the situation with regards to admissions improved from 7\% in 2011, $27 \%$ (2012), 24\% (2013), 25\% (2014), and 27\% (2015). Hence, over two thirds of the applicants (some of whom had passed UTME) were not admitted.

Table 2: JAMB Applications and Admissions by Gender, 2008-2015

\begin{tabular}{lllllllll}
\hline & Year & Male & $\begin{array}{c}\text { Applicants } \\
\text { Female }\end{array}$ & Total & Male & $\begin{array}{c}\text { Admitted } \\
\text { Male } \\
(\mathbf{\%})\end{array}$ & $\begin{array}{l}\text { Female } \\
\text { Female } \\
(\%)\end{array}$ & Total \\
\hline 2008 & 598688 & 455394 & 1054082 & 71328 & 60.0 & 47363 & 40.0 & 118691 \\
2009 & 743820 & 562285 & 1306105 & 115133 & 60.0 & 75653 & 40.0 & 190786 \\
2010 & 800111 & 604000 & 1404111 & 122055 & 63.5 & 70200 & 36.5 & 192255 \\
2011 & 833,081 & 660,526 & 1493607 & 60,525 & 61.6 & 37,771 & 38.4 & 98296 \\
2012 & 839,218 & 664,715 & 1503933 & 237,753 & 58.0 & 172,404 & 42.0 & 410157 \\
2013 & 934,828 & 733,486 & 1668314 & 230,459 & 57.6 & 169,810 & 42.4 & 400269 \\
2014 & 880,156 & 671,133 & 1551289 & 235,489 & 60.0 & 158,084 & 40.0 & 393573 \\
2015 & 742,294 & 587,582 & 1329876 & 208,085 & 58.8 & 145,612 & 41.2 & 353697 \\
Total & $\mathbf{6 , 3 7 2 , 1 9 6}$ & & $\mathbf{1 1 3 1 1 3 1 7}$ & $\mathbf{1 , 2 8 0 , 8 2 7}$ & & $\mathbf{8 7 6 , 8 9 7}$ & & $\mathbf{2 , 1 5 7 , 7 2 4}$ \\
\hline
\end{tabular}

Source: JAMB Report, 2017 and https://punching.com/Jamb,2019

From Table 2, the gender parity (in admission) from the benchmark (55\%/45\%/ male/female) as expected by the 2009 Education Reform agenda has not been achieved in JAMB since $2011(61.6 \% / 38.4 \%)$. Subsequently, the parity ratio improved marginally, 2012 (58\%/42\%), 2013 (57.6\%/42.4\%), 2014 (60\%/40\%), and 2015 $(58.8 \% / 41.2 \%)$. 
Figure 2: Trend in Percentage of Male and Female Admitted by JAMB, 2008-2015

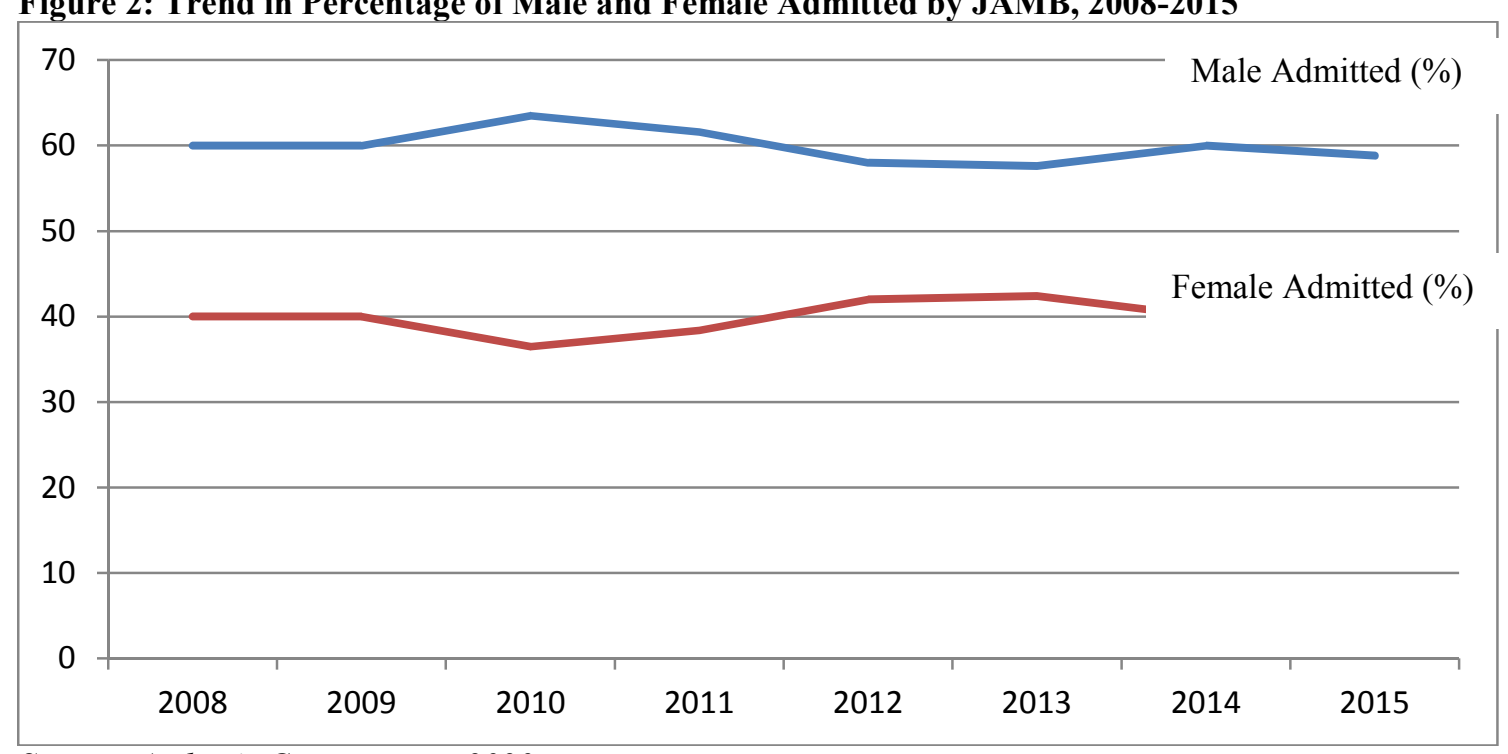

Source: Author's Computation, 2020

Figure 2 shows the trend in the percentage of male and female candidates admitted in the Nigeria tertiary institutions from 2008 to 2015 which revealed that the percentage of male candidates admitted is higher than that of female candidates admitted, with the largest gab witnessed in $2010(63.5 \% / 36.5 \%)$.

\section{DISCUSSION}

Based on facts presented, it is obvious that the challenges of access in tertiary education remain formidable. The rate of admission of $6 \%$ into tertiary level education as against the generally accepted minimum of $16 \%$ for meaningful economic development brings out the challenges clearly (FME Roadmap, 2009). This is as a result of the low carrying capacity of tertiary institutions which stands at 150,000 for the NUS while annual demand is about 1 million. For the Polytechnic system, the gross carrying capacity of 158,370 and the actual is 340,535 (more than $100 \%$ over-enrolled); and for the Colleges of Education 118,129 while the actual is 354,387. The situation is further compounded by preference for university education. On the other hand, Polytechnics and Colleges of Education are having difficulty attracting qualified candidates. For instance, in 2008/2009 academic session, a total of 957,172 applied for placement in universities as against 232,598 and 58,819 for Polytechnics and Colleges of Education respectively through JAMB.

The NUC policy on carrying capacity also posed a daunting challenge to access to education. By this policy, the NUC has pegged the number of students that can be admitted by each university in Nigeria every year. This has obviously reduced considerably in recent years the admission into Nigerian universities. This was made clearer by the Federal Ministry of Education (2009), which noted that the carrying capacity of NUS stands at 150,000 while the actual demand is about 1 million. In 2011/2012 academic session, a total of 1493,604 candidates sat for the UTME conducted by the Joint Admission and Matriculation Board. The results announced showed that 842,851 candidtaes scored below 200 marks over 400, indicating less than $45 \%$ passed the examination. JAMB later fixed 180 marks as minimum for university students and 160 for Colleges of Education and Polytechnic (Edukugbo, 2011). Edukugbo (2011) went further to posit that when the Executive Secretary of NUC was asked about the admission quota, he said one cannot be too sure, but thought that about 400,000 students may be admitted into all the universities in Nigeria but cautioned that most of them are still not qualified due to some shortcomings. The 2009 Educational Reform benchmark (parity ratio) of 55\% male and 45\% female from 2011 were not cumulatively achieved. As submitted by JAMB (2017), gender disparity in admissions figures from 2008-2012, the proportion of candidates was as thus; $2008-6.8 \%$ males, $4.5 \%$ females; $2012-8.7 \%$ males, $6.2 \%$ females, and cumulatively, (59\% male, $41 \%$ females) which represented a $4 \%$ shortfall from the target of $45 \%$ female. The UNESCO, "2010 Nigeria Country Report" also confirmed 41\% female participation in educational opportunities in Nigeria. That cultural factor inhibits, the Girl-child in Northern Nigeria from benefitting from educational opportunities (hawking and early marriages). And that the media campaigns, mobilization/enlightenment in this regard will enhance more female participation and eventual transition to tertiary education. This was further supported by studies on the subject by Anyebe (2015) in the North-East, Nigeria.

\section{SUMMARY OF FINDINGS}

i. From 2011-2016, the 20\% annual increase in admission benchmark though reasonably achieved with $62 \%$ positive variance, the gap between those admitted and candidates left out continue to grow, thus out of 
the 7.5 million candidates that applied for placements into Nigerian tertiary institutions, only about 1.7 million candidates were admitted (21.9\%) leaving out $78 \%$ or 5.9 million from opportunities for tertiary education, some of whom were qualified but limited by quota and carrying capacity.

ii. The benchmark on gender parity of 55\% male and $45 \%$ female candidates were also not achieved in our tertiary institutions. For example, JAMB- (61.6\% male 38.4\% female) with the highest gabs in 2010 $(63.5 \%, 36.5 \%)$

\section{CONCLUSION AND RECOMMENDATIONS}

Based on the facts presented and discussed in this paper, it is observed that over the years, generally, the quality of education is on the decline since the 1990s. Notably, out of the 7.5 million candidates that applied for placements into Nigerian tertiary institutions (2011-2016), only about 1.7 million candidates were admitted (21.9\%) leaving out $78 \%$ or 5.9 million from opportunities for tertiary education, some of whom were qualified but limited by quota and carrying capacity. The benchmark on gender parity male $(55 \%)$ and female $(45 \%)$ is yet to be achieved since 2011 at the national level (JAMB 61.6\%/38.4\%).Based on the foregoing findings and conclusions, the following suggestions were offered:

i. Access to education can be improved through expansion of the activities of National Open University of Nigeria (NOUN), Open and Distance Learning (ODL) and National Teachers' Institute(NTI) to improve their facilities to make them more relevant and globally competitive. Also, the carrying capacity of tertiary institutions should be increased without compromising standards. Equally, there is the need to increase awareness and support for alternative route to higher technical education through Innovation Enterprise Institutions (IEIs) through aggressive branding and marketing strategies; more programmes for Technical and Vocational Education (TVE) in the tertiary institutions to increase alternative access to educational opportunities.

ii. Gender (female) access to tertiary institutions can be improved through continuous gender focused education programmes by considering policies such as quota-based admission, fees reduction, scholarships and other incentives based on gender (with female bias). Also to ensure tertiary institutions implement the $55 \%$ male, $45 \%$ female benchmarks with rewards and sanctions for defaulters.

\section{REFERENCES}

Akpan, C.P. \& Etor, C.R. (2016).Accreditation of academic programmes and quality University education in South-South, Nigeria. International Journal of Education Studies, 13(2), 1682-4377.

Anselm, U. (2013). Effects of reforms in Nigerian education sector: Journal of Humanities and Social Sciences, 15(6), September.

Anyebe, A.A. (2017).Gender differential and Girl-child education in Nigeria, ABU Journal of Public Administration, 6(2),245-356.

Clark, N. (2005). Public policy and technology change in Africa: Aspects of instruction and management capacity. Journal of Economic Studies, 27(1),7593.

Edukugbo, E. (2011). Admission scramble: It's survival of the brightest. Vanguard Newspaper, September, pp. 28.

Enaohwo, J.K. (2008). Access, cost and quality in Nigerian education. In: B.G. Nworgu \& E.I. Eke (Eds.) Access, quality and cost in Nigerian education (pp.3-19). Published Proceeding of the 23rd Annual Congress of the Nigerian Academy of Education.

Federal Government of Nigeria, (1999). The 1999 Constitution, Federal Republic of Nigeria.

Federal Government of Nigeria, (2007). NUC Annual Report.

Federal Ministry of Education, (2007). 10 Year Strategic Plan, p.30

Federal Ministry of Education, (2009).Roadmap for the Nigeria Education reforms. Abuja, Nigeria Author.

Federal Ministry of Education, (2014). Annual Report Abuja (C) 2015, pp. 4-63.

Federal Ministry of Education, (2015). 4-years Strategic Plan for the Development of the Education Sector: 20112015, Final Report of Key Achievements. Abuja, pp. 27-28.

Isa L.B (2020). Effect of the evaluation of the 2009 education reforms on access and quality in selected federal institutions, unpublished PhD thesis, Ahmadu Bello University, Zaria, Nigeria.

Joint Admissions and Matriculation Board, (2017).Jamb Report, https://www.jamb.org.ng.

Joint Admissions and Matriculation Board, (2019).Jamb Report, https://punching.com.

Okebukola, P.A. (2005). Quality assurance in the Nigerian university system. Nigerian Journal of Curriculum Studies, 12(3), 1-5.

Okebukola, P.A. (2006). Principle and policies guiding current reforms in Nigerian Universities. Council for the Development of Science Research in Africa, 4(1) pp.25-36.http://www.codesria.org/IMG/pdf/02OKEBUKOLA.pdf

Okebukola, P.A. (2008). Quality assurance mechanisms and academic mobility in Anglophone countries: Case 
study of Nigeria. Paper presented at the capacity building workshop on the License-Master-Doctorate (LMD) reform held at Universite Gaston Berger, Saint Louis, Senegal September 19-20.

Okeke, E.A.C (2008). Access in Nigerian education. In: B.G. Nworgu, \& E.I. Eke (Eds) Access quality and cost in Nigerian academy of education.

Oyaziwo, A. \& Philips, O. (2012).Access to university education in Nigeria, Present challenges and suggestive for the future, Journal of Africans Educational Research Network xil 2, No I

Shagari, M. Bello, H. \& Umar, S. (2013). The role of nomadic education in developing nomadic community. 2(6) August.

UNESCO Country Report, (2006).Decentralization of education in Nigeria, September, p.29.

UNESCO Country Report, (2010). https://www.ibeunesco.org.

Yoloye, E.A. (1989).(ed). Resources for science, mathematics and technical education in Nigeria secondary schools: A National Survey. Lagos: Federal Ministry of Science and Technology. 